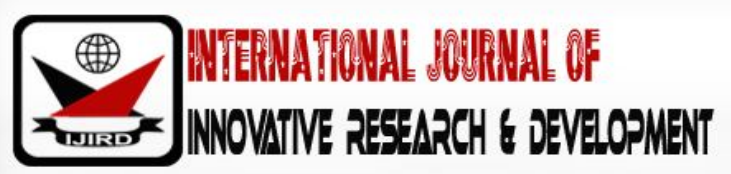

ISSN 2278 - 0211 (Online)

\section{Factors Affecting Savings of Women Lead Households in Self Help Groups: The Case Study on Wolailta Sodo Town}

\author{
Mr. Asrat Libiyos Ganebo \\ M. Sc Student, College of Business \& Economics, Wolaita Sodo University, Ethiopia \\ Mr. Temesgen Tera Odiro \\ Lecturer, College of Business \& Economics, Wolaita Sodo University, Ethiopia
}

\begin{abstract}
:
Self Help Group (SHG) is mainly considered as mutual assistance group through which individuals undertake common activities to improve their own lives. It is an approach in which women are organized in groups of 15-20 members by affinity basis. This research was aimed to assess the factors affecting savings of women-led households in self-help groups. Multistage sampling technique was deployed in the study. From 1800 registered SHG members, the sample size of 252 samples identified through simple random sampling technique. Household survey and in-depth interview were conducted and data captured using structured questionnaire. Both primary and secondary data were used for analysis. Quantitative data collected were analyzed using SPSS 21 version and presented the mean, percentage, chi-square, T-value and binary logit model output according to research objectives. Descriptive statistics was computed followed by binary logit model that revealed: education level of SHGs members, family size, social participation, number of trainings received, members' perception, and annual income and participation in generating activities (IGAs) found to be significant. According to paired sample T-test result saving improvement between two consecutive years was not as such satisfactory. The final recommendations forwarded were: due consideration should be given to reduce SHGs members' social ceremonies celebrations, promoting family planning program, focusing on functional adult literacy, envision groups, tailored training of members and IGAs promotion by both government and other organizations working on SHGs development as they had either positive or negative influence on WLHHS saving improvement.
\end{abstract}

Keywords: Self help group, women-led households, saving

\section{Introduction}

Saving is among important variables for economic growth of any country. Saving is aboutincome that is not consumed by immediately buying goods and services (Prinsloo, 2000; Manyama, 2007). Saving constitutes the basis for capital formation, investment and growth ofa country (Nga, 2007; Nwachukwu and Odigie, 2009).According to Deaton (2005) and Rogg (2006) serious problem confronting poor countries including Ethiopia is the savings and investment gap. Because of this gap, these countries find it difficult to finance investments needed for growth from domestic saving. It is also common to see these countries to finance their investment in the short run partly through domestic government borrowings and/ or foreign loan and grants but this would significantly increase the country's debt burden and would not be a solution in the long run

Savings Groups (SGs) and Self-Help Groups (SHGs) have emerged as viable alternatives to traditional microfinance for providing community-based financial services in poor, primarily rural communities in Africa, Asia, Latin America and the Caribbean. Savings Group models draw from traditional saving circle groups, rotating savings and credit associations (ROSCAs), first adapted by Cooperative for Assistance and Relief Everywhere (CARE) Niger in the 1990s. The millions of individuals involved in these groups (over 10 million in Africa) follow a standard model in which groups to meet regularly, contribute an agreed upon amount on a regular basis, and loan out the accumulated sum to their members at an agreed upon fee. Typically, Savings Groups share-out their savings, with accrued interest, to members on an annual basis. Share-outs are often timed for when households require additional cash. (Masilela, E. 2006).

The concept of SHG is first introduced by Laureate Mohamed Yunus in Bangladesh and nowadays it touched the greatest part of the world (Narang, 2012). The purpose of the groups is enabling the group members to come together and combine their resource in order to access low-cost financial service with a process of self-management and development. They can be formed and organized by authorized institutions or sometimes they can be formed by the common interest of individuals living in the same life condition. The group members save a certain money together for some period of time that 
can be used as loan so that they can engage in different small business activities to improve their economic life and living conditions. Beyond this they help each other during stiff problems by establishing strong social network among the group members. Nevertheless, the vital purpose of the SHG program is to pave the way to access credit in order to help the members to fight against poverty (Das, S. K. (2012).

Household savings is defined as that part of current income, after the payment of direct taxes, which is not consumed or transferred for future consumptions. Saving includes current disbursements made in the form of a reduction in household liabilities, such as repayment of loans. By contrast, any portion of the current expenditure of households not financed by current income but rather by the use of credit represents an increase in the financial liabilities of individuals and is treated as negative saving. In addition, household saving includes regular and recurring employer and employee contributions to pension and insurance funds and the interest earned on those funds. Saving is also defined in terms of flows in the current account and excludes any capital gains and losses (Schultz, 2005; Nga, 2007; Cronje, 2009).

\subsection{Statement of the Problem}

Household savings is a key focus of many developed and developing countries. And other community development programs test the efficacy and impact of various saving initiatives as tools to promote economic independence among low-tomoderate income households. Through education, information, and coaching, individuals become motivated to save; partnerships with financial institutions provide access to financial accounts and products that help consumers implement their savings plans (R. Ghoshi, 2004)

Low levels of savings make poor and low-income households particularly vulnerable to problems arising from lack of access to emergency funds. A substantial body of research in the field of family financial management measures the presence of savings by a household's ability to meet short-term emergencies (Noah, 2008).

In developing countries, credit access and terms, have been the major setbacks in women economic empowerment (Das, 2012). Lack of collateral security, need of small-sized loans which is expensive, high bank transaction costs have been the major hindrance (Vetrivel \& Mohanasundari, 2011.The need to create a grassroots organizational base to enable poor women to come together, to analyze their issues and problems themselves, and to fulfill their needs has been strongly advocated in countries like Indian, Bangladesh, and Pakistan (Vetrivel \& Mohanasundari, 2011). Grassroots organization such as the selfhelp group has enable women secure their tomorrow through pooling their little financial resources in terms of savings. These savings are crucial in two aspects they are lend to members as loans and part of it is used to access loan from financial institutions (Vetrivel \& Mohanasundari, 2011). The Self - Help Group (SHG) also empowers its members through equipping them with new skills through frequent trainings. Participation in Self-help groups has been much hypothesized to bring women economic empowerment (Moon, 2011; Panda, 2009; Tesoriero, 2006).

It is clear that the poor can save and needs a comprehensive focus on the determinants of saving rate among the Women led Households saving (WLHHs) SHG member, in corollary to their poor earning abilities. The present study attempts to attain possible solutions and driving forces to push poor women to promote their saving rate. Knowing these can help women empowerment through SHG promoting organization, state and local policy makers and other community development organizations to work with low-income families, especially WLHHs.

\subsection{Objectives}

\subsubsection{General Objectives}

The general objective of the study was to identify the major factors that affect the savings of women Led household members of Self Help Groups in Sodo Town.

\subsubsection{The Specific Objectives}

- To investigate the current savings status of women members of the Self-Help Group in the Wolaita Sodo town.

- To identify the potential factors affecting the savings of women belonging to Self Help Wolaita Sodo town.

- To find out the Marginal Propensity to Save of WLHH's in the Self-Help Group in the Wolaita Sodo town. 


\section{Conceptual Framew ork of the Study}

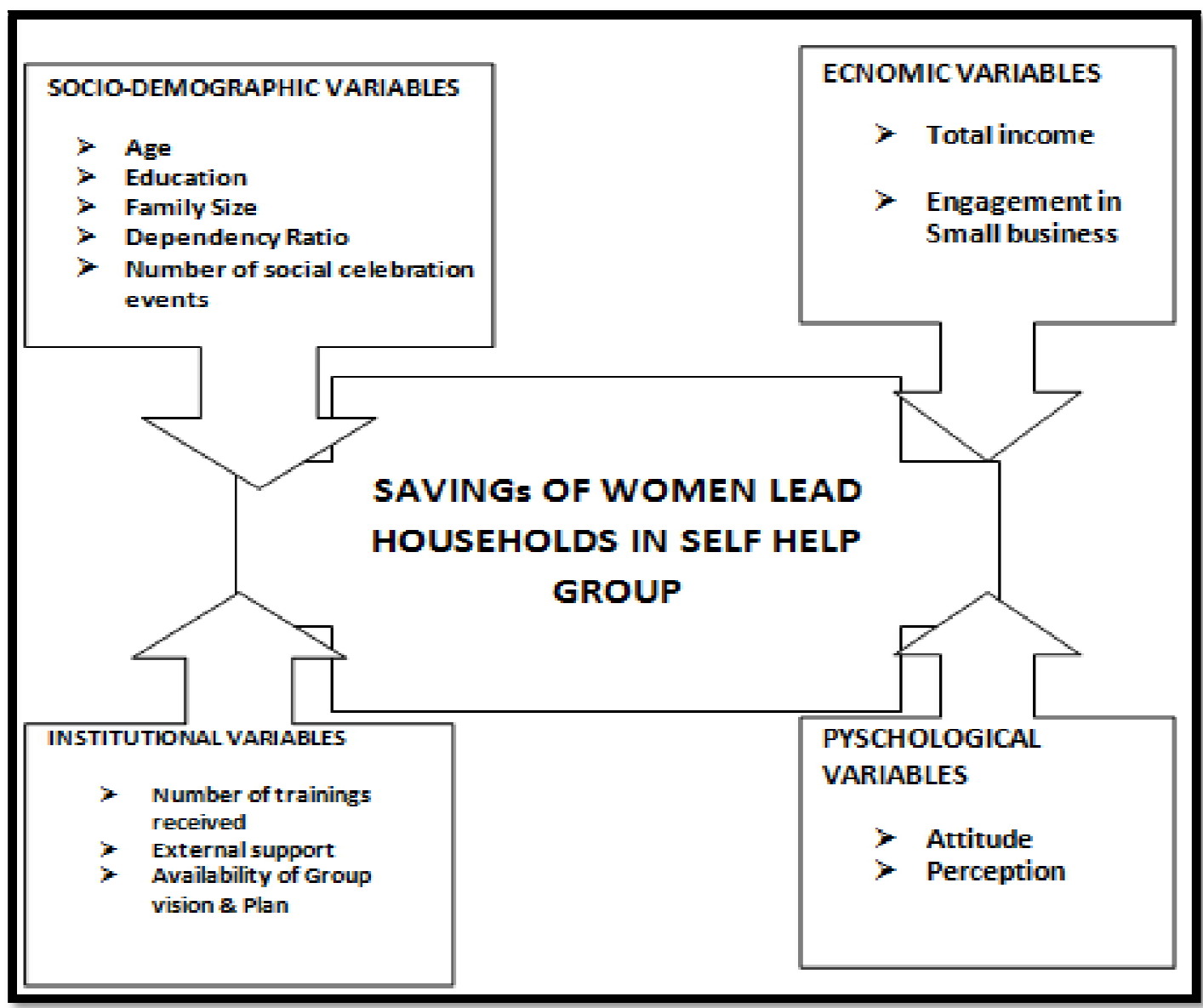

Figure 1: Conceptual Framework of the Study, 2017

Source: Observation and Literature Review

\section{Research Methodology}

\subsection{Study Design}

The study design was taken both the exploratory and descriptive nature since the study was meant to know the savings status of women led household and major factors affect women led household saving that needs information including socio-demographic, economic, institutional, and psychological wings. It has taken the position of descriptive in describing general socio-economic characteristics of the target group by age group, source and size of income, address, level of education, family size, etc. The study was also designed as exploratory since it implemented methods to investigate the sociodemographic, economic, institutional and psychological aspects of the target groups.

\subsection{Target Population of the Study}

'According to census result of 2007, the Soddo town administration has a population of 108,509, out of which 57,271 are male and 51,238 are female. The annual population growth rate of the city administration is about 5.4. Soddo town has social and economic services centers established by various development actors including GOs, NGOs and community at large for the last decades on education, health,infrastructure and roads. Total women organized in SHG in Soddo town by TDA were around 120 self-help groups or 1800 member(TDA annual report, 2016).

\subsection{Sampling Design}

Within the objective of meeting the esteemed key questions of the study, the sample was focused only WLHH members organized in the SHG who have stayed for three years and above. Because this, the study tried to identify the saving related issues of SHG which in turn has given the clue to study the factors affect savings of the target group after being the member of a particular SHG in time path. The younger SHG members, less than 3 years were not included as part of this study. It also focused on WLHH only because the SHG concept entirely focuses on poor and marginalized groups as most of the WLHH belong to poor and marginalized groups (Tear Fund, 2016). According to TDA annual report, 40\% of the selected SHGs contain 
WLHHs. Therefore, the study entirely focuses on 720 WLHH ( $40 \%$ of 1,800 women SHG savers organized and supported by TDA in the town (TDA, 2015).

\subsection{Sample Size Determination}

The sample size was determined to represent the sample population under investigation for this study by using a Cochran model for sample size determination as indicated by Yamane (1967). The Yamane formula is:

$$
\mathrm{n}=\frac{\mathrm{N}}{1+\mathrm{N}(\mathrm{e})^{2}}
$$

Where: $\mathrm{n}=$ sample size;

$\mathrm{N}=$ total number of households in the selected SHG;

e = maximum variability or margin of error $5 \%(0.05)$;

$1=$ probability of the event occurring.

As to TDA (2015) data, there are 720 Woman led households engaged in SHG saving in the selected area who stayed more than three years period. Therefore, by using Yamane (1967) formula, the sample size applied in the study was:

$$
\mathrm{n}=\left[720 /\left\{\left(1+720(0.05)^{2}\right\}\right]=257\right.
$$

In order to develop reliability of the responses, the purposive sampling, for selecting the area and the simple random sampling technique, one of the most commonly used probability sampling techniques, was applied to pick up 257 targeted WLHH respondents at household level. Therefore, at first stage, the researcher was purposely selected local NGO working on SHGs by using purposive sampling because this local NGO are the only major organization that promote SHGs in the sodo town. At second stage of sampling, the researcher randomly selected 257 WLHHs from TDA Merkato, mehal and Arada sub town respectively where these were selected for final targeted sampling because the total population frame was easily available to select sampling purposely from the LNGO TDA (see figure 2).

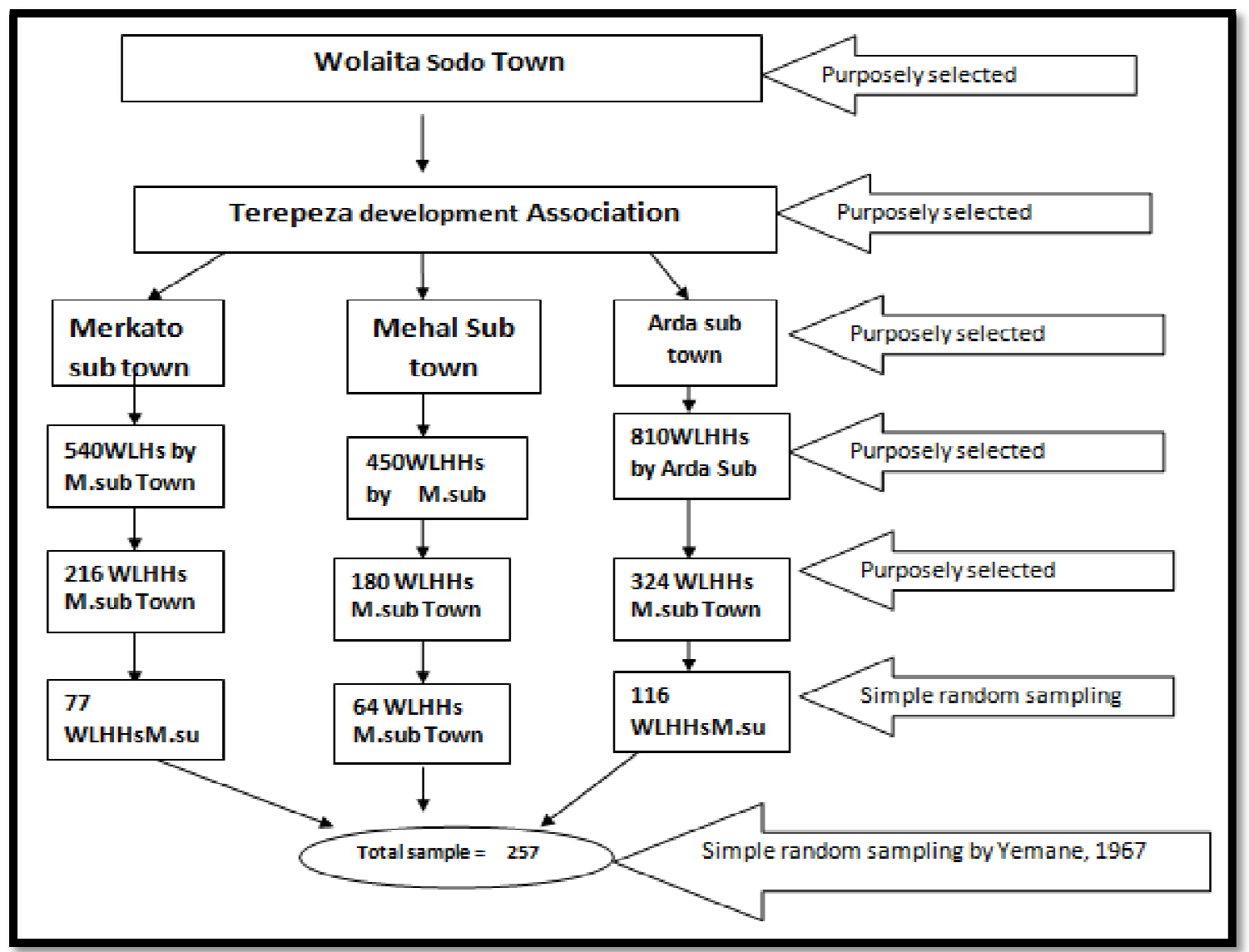

Figure 2: Sampling Procedure

Source: Document from the SHG, TDA

\subsection{Data Source}

The study generated the required data from both primary and secondary sources. As to the primary data, information was collected from target groups (SHG members in Soddo Town those organized by local NGO - Terepeza Development Association). As to the secondary source, information was collected from individual SHG member pass book and the group financial records. 


\subsection{Econometric Analysis}

To find the relationship between dependent variable, savings of WLHHs, and independent variables, the research applied the descriptive and binary logit model. It is believed that, this model more represent the interrelationship among variables and associate the strength/ weakness of the determinant variables.

\subsection{Model Specification}

In statistical modeling, regression analysis is a set of statistical processes for estimating the relationships among variables. It includes many techniques for modeling and analyzing several variables, when the focus is on the relationship between a dependent variable and one or more independent variables.

Mathematical Representation of the Model was shown as follows: -

Factors that affecting WLHH SHG Total savings

WLHHSI $=f\left(\beta_{0}+\beta_{1}\right.$ WLHHAG $+\beta_{2}$ WLHHFMLSZ $+\beta_{3}$ WLHHEDUC $+\beta_{4}$ WLHHDPNDCY + $\beta_{6}$ WLHHINCM $+\beta_{7}$ TINCWHH $+\beta_{8}$ WLHHIGA $+\beta_{9}$ WLHHTRNING $+\beta_{10}$ WHHVPLAN $\beta_{13}$ WLHHATTITUDE $+\beta_{14}$ WLHHPERCEPT $+\varepsilon t$

Where,

WLHHAG =Age of WLHHs

WLHHEDUC $=$ Educational level of WLHHs

WLHHDPNDCY $=$ Dependency ratio of WLHHs

WLHHFMLSZ = Family size of WLHHs

WLHHSOCLPRT = Major social celebrations of WLHHs

WLHHSVGBFSHG=WLHH Saving trained before SHG

WLHHTRNING = Total SHG trainings received of WLHHs

$\mathrm{WLHHH}=$ Perception towards the importance savings of WLHHs

WLHHATTITUDE $=$ Attitude towards the importance savings of WLHHs

WLHHVSNPLN $=$ vision and plan of WLHHs

WLHHIGA = Small business engagements of WLHHs

WLHHEXTRNLSPT $=$ External support of WLHHs

WLHHINCME $=$ Total income of WLHHs

The expected signs of the coefficients are as assumed below: -

$\beta 1, \beta 2, \beta 6, \beta 7, \beta 8, \beta 10, \beta 11, \beta 12 \& \beta 13>0$ AND $\beta 3, \beta 4, \beta 5, \& \beta 9<0$

\section{Results and Discussion}

\subsection{Annual savings status of respondents}

\begin{tabular}{|c|c|c|c|c|}
\hline Years & Mean saving & St. Dev & \multicolumn{2}{|c|}{ Paired Mean difference } \\
\hline 2014 (Year 1) & 323.76 & 150.914 & Yr 2 - Yr 1 & Yr 3 - Yr 2 \\
\hline 2015 (Year 2) & 312.41 & 209.290 & -11.35 & \\
\hline 2016 (Year 3) & 318.54 & 198.175 & & .13 \\
\hline Correlation & & & .409 & .147 \\
\hline
\end{tabular}

Table 1: Respondents Mean Annual Savings Comparison

Source: Compiled from Secondary Data, 2017

$$
\mathrm{P} \text { Value }=0.000^{* * *}
$$

\subsection{Dependency Ratio of Respondents}

\begin{tabular}{|c|c|c|c|}
\hline Changes in saving & N & Mean dependent members & Std. Deviation \\
\hline Yes, my saving has been improved & 149 & 1.83 & 1.528 \\
\hline No, my saving didn't change & 103 & 3.41 & 1.863 \\
\hline
\end{tabular}

Table 2: Respondents Dependency Ratio

Source: Compiled from Primary Data, 2017

$$
\mathrm{T}=-2.853 \quad \mathrm{P} \text { Value }=0.005^{* *}
$$

One more dependent household member demands additional cost of saving. T-test value, -2.853 confirmed the inverse relationship between saving improvement and higher dependency ratio. The variable had significant influence on SHGs members saving improvement with $5 \%$ probability level. 
4.3. Respondents Expenses in Social Ceremonies

\begin{tabular}{|c|c|c|c|}
\hline Expenses On Social Ceremonies & \multicolumn{2}{|c|}{$\begin{array}{c}\text { Is There Positive Change In Your Saving In } \\
\text { SHGs In The Past Three Years? }\end{array}$} & Total \\
\hline & $\begin{array}{c}\text { Yes, my saving has been } \\
\text { improved }\end{array}$ & $\begin{array}{c}\text { No, my saving } \\
\text { didn't change }\end{array}$ & \\
\hline Yes & $39(15.5 \%)$ & $47(18.7 \%)$ & $86(34.1 \%)$ \\
\hline No & $110(43.7 \%)$ & $56(22.2 \%)$ & $166(65.9 \%)$ \\
\hline Total & $149(59.1 \%)$ & $103(40.9 \%)$ & $252(100.0 \%)$ \\
\hline
\end{tabular}

Table 3: Respondents Participation in Social Ceremonies Source: Compiled from Primary Data, 2017

$$
\mathrm{X}^{2}=10.255 \quad \mathrm{P} \text { value }=0.001 * * *
$$

Of the sample respondents 39(15.5\%) reported that they had celebrated one or more of these ceremonies and they had improved their savings whereas $110(43.7 \%)$ stated that they had not celebrate a number of social ceremonies and their saving had been improving. Of the sample respondents, 47(18.7\%) reported that they had celebrated one or more social ceremonies and their saving hadn't been improved. On the other hand, $56(22.2 \%)$ were not celebrating any of social ceremonies while their saving had not been improved. The survey results clearly showed that, SHGs members who had participated in more social ceremonies spent a large amount of money on it and they could not be able to improve their savings. The chi-square test result proved that there is negative relationship between participating in more social ceremonies and improving savings in their SHGs. The variable had significant influence with 1\% probability level.

\subsection{Saving Related Training of Respondents}

\begin{tabular}{|c|c|c|c|}
\hline Have taken training & \multicolumn{2}{|c|}{$\begin{array}{c}\text { Is there positive change in your saving in SHGs in the past } \\
\text { three years? }\end{array}$} & Total \\
\hline & Yes, my saving has been improved & $\begin{array}{c}\text { No, my saving didn`t } \\
\text { change }\end{array}$ & \\
\hline Yes & $120(47.6 \%)$ & $69(27.4 \%)$ & $189(75 \%)$ \\
\hline No & $29(11.5 \%)$ & $34(13.5 \%)$ & $63(25 \%)$ \\
\hline Total & $149(59.1 \%)$ & $103(40.9 \%)$ & $252(100.0 \%)$ \\
\hline
\end{tabular}

Table 4: Respondents Training Status

Source: Compiled from Primary Data, 2017

$$
\mathrm{X}^{2}=5.961 \quad \text { P Value }=0.015^{*}
$$

\begin{tabular}{|c|c|c|c|c|c|c|c|}
\hline \multirow{2}{*}{\multicolumn{2}{|c|}{$\begin{array}{c}\text { Attitude towards saving in } \\
\text { SHG }\end{array}$}} & \multicolumn{5}{|c|}{ I behave in a manner to strengthen my saving in SHG } & \multirow{2}{*}{ Total } \\
\hline & & $\begin{array}{l}\text { Strongly } \\
\text { Disagree }\end{array}$ & Disagree & Neutral & Agree & $\begin{array}{c}\text { Strongly } \\
\text { Aqree }\end{array}$ & \\
\hline \multirow{2}{*}{$\begin{array}{c}\text { Is there positive change in } \\
\text { your saving in SHGs in the } \\
\text { past three years? }\end{array}$} & Yes & 0 & $3(1.2 \%)$ & $28(8.3 \%)$ & $68(27 \%)$ & $57(22.6 \%)$ & $\begin{array}{c}149 \\
(59.1 \%)\end{array}$ \\
\hline & No & 0 & $11(4.4 \%)$ & $29(11.5 \%)$ & $35(13.9 \%)$ & $28(11.1 \%)$ & $\begin{array}{c}103 \\
(40.9 \%)\end{array}$ \\
\hline Total & & 0 & $14(5.6 \%)$ & $50(19.8 \%)$ & $103(40.9 \%)$ & $85(33.7 \%)$ & $252(100 \%)$ \\
\hline
\end{tabular}

4.5. Respondents Perception about Saving in SHGs

Table 5: Respondents Attitude towards Saving in SHG

Source: Compiled From Primary Data, 2017

$$
\mathrm{X}^{2}=18.539 \quad \text { PValue }=0.000^{* * *}
$$

Regarding women led households' members of SHGs; they behave in a manner to saving. As can be seen from the Table 5, $3(1.2 \%)$ disagree on the statement that describes as their saving habit has been improved by being a member of SHG, $28(8.3 \%)$ were neutral for the statement, $68(27 \%)$ agreed as their saving had improved, and $57(22.6 \%)$ members were 
strongly agreed as their saving incomparably improved. On the other hand, $11(4.4 \%), 29(11.5 \%), 35$ (13.9\%), and 28 $(11.1 \%)$ were disagreed, neutral, agreed and strongly agreed respectively and their saving had not improved.

4.6. SHGs Have Their Own Vision and Plans to Improve Savings

\begin{tabular}{|c|c|c|c|}
\hline \multirow[t]{2}{*}{$\begin{array}{l}\text { Self Help Groups } \\
\text { Vision and plan }\end{array}$} & \multicolumn{2}{|c|}{$\begin{array}{c}\text { Is there positive change/ improvement/ in your saving } \\
\text { in SHGs in the past three years? }\end{array}$} & \\
\hline & $\begin{array}{l}\text { Yes, my saving has been } \\
\text { improved }\end{array}$ & $\begin{array}{l}\text { No, my saving didn`t } \\
\text { change }\end{array}$ & Total \\
\hline Have group vision and plan & $146(57.9 \%)$ & $88(34.9 \%)$ & $234(92.9 \%)$ \\
\hline Do not have group vision and plan & $3(1.2 \%)$ & $15(6 \%)$ & $18(7.1 \%)$ \\
\hline Total & $149(59.1 \%)$ & $103(40.9 \%)$ & $252(100.0 \%)$ \\
\hline
\end{tabular}

Table 6: Respondents Vision and Plans

Source: Compiled From Secondary Data, 2017

$\mathrm{X}^{2}=14.461 \quad$ P Value $=0.000^{* * *}$

As can be seen from the above Table 6, about 146 (57.9\%) of the SHGs sample respondents had vision and plans in their group and saving had improved whereas 3 (1.2\%) SHGs members had no group vision and plans but their saving had improved. On the other hand, 88(34.9\%) of respondents did have group vision and plans but their saving had not improved whereas 15 (6\%) respondents had no group vision and plans and they did not improve their saving. As survey result had shown that the relationship between SHG group vision and plans is positive. The Chi-square test confirmed that the relationship is significant by $1 \%$ probability level.

\subsection{Access to external support}

\begin{tabular}{|c|c|c|c|}
\hline \multirow{2}{*}{ External support } & \multicolumn{2}{|c|}{$\begin{array}{c}\text { Is there positive change/ improvement/ in your saving in SHGs in } \\
\text { the past three years? }\end{array}$} & \\
\hline & Yes, my saving has been improved & No, my saving didn't change & Total \\
\hline Yes & $35(13.9 \%)$ & $21(8.3 \%)$ & $56(22.2 \%)$ \\
\hline No & $114(45.2 \%)$ & $82(32.5 \%)$ & $196(77.8 \%)$ \\
\hline Total & $149(59.1 \%)$ & $103(40.9 \%)$ & $252(100.0 \%)$ \\
\hline
\end{tabular}

Table 7: Respondents Access to External Support

Source: Compiled from Primary Data, 2017

$$
\mathrm{X}^{2}=0.339 \quad \text { P value }=0.560
$$

As illustrated in Table 7, from total respondents 35(13.9\%) had got external support and their saving had improved whereas 114 (45.1\%) did not accessed any external support but their saving had improved. On the other hand, 21 (8.3\%) had got external support but their saving had not improved and $82(32.5 \%)$ of respondents did not access any external support and their saving had not improved as well. The chi-square and probability value showed that the variable had insignificant relationship with SHGs members saving improvement.

\subsection{Econometric Results}

\begin{tabular}{|c|c|c|}
\hline Variable & Tolerance & VIF \\
\hline Age of WLHH & .732 & 1.366 \\
\hline Family size of WLHH & .563 & 1.772 \\
\hline Dependency ratio of WLHH & .185 & 5.405 \\
\hline Total Income of WLHH & .206 & 4.864 \\
\hline
\end{tabular}

Table 8: The VIF and Tolerance of Continuous Explanatory Variables

Source: Compiled from Primary Data, 2017 


\begin{tabular}{|c|c|c|c|c|c|c|c|c|}
\hline Variable & Wlhheduc & Wlhhsoclprt & Wlhhtrning & Wlhhpercptn & Wlhhattd & Wlhhvsnpln & Wlhhiga & $\begin{array}{c}\text { Wlhhig } \\
\text { a }\end{array}$ \\
\hline Wlhheduc & 1 & 0.371 & 0.120 & 0.178 & 0.008 & 0.306 & 0.347 & 0.182 \\
\hline Wlhhsoclprt & & 1 & 0.083 & 0.305 & 0.119 & 0.472 & 0.368 & 0.205 \\
\hline Wlhhtrning & & & 1 & 0.054 & 0.091 & 0.204 & 0.273 & 0.039 \\
\hline Wlhhpercptn & & & & 1 & 0.067 & 0.006 & 0.172 & 0.185 \\
\hline Wlhhattd & & & & & 1 & 0.264 & 0.154 & 0.116 \\
\hline Wlhhvsnpln & & & & & & 1 & 0.403 & 0.150 \\
\hline Wlhhiga & & & & & & & 1 & 0.053 \\
\hline Wlhhextspt & & & & & & & & 1 \\
\hline
\end{tabular}

Table 9: Contingency Coefficient for Discrete Variables

Source: Compiled from Primary Data, 2017

\subsubsection{Econometric Model Output}

In the preceding parts of this thesis binary logit analysis of important explanatory variables, which are expected to have influence on savings of women led SHG members households were presented. In this section, the selected explanatory variables were used to estimate factors affecting saving improvement of women led households in SHGs. Aneconometric model was fitted to estimate the effects of the hypothesized explanatory variables on the probabilities of saving improvement or not.

\begin{tabular}{|c|c|c|c|c|}
\hline Variables & $\begin{array}{c}\text { Estimated Coefficient } \\
\mathbf{( B )}\end{array}$ & $\begin{array}{c}\text { Odds Ratio } \\
(\mathbf{E x p ( B ) )}\end{array}$ & Wald & Sig. \\
\hline WLHHAG & .025 & 1.026 & .377 & .539 \\
\hline WLHHEDUC & .622 & 1.863 & 6.826 & $.009^{* *}$ \\
\hline WLHHDPNDCY & -.006 & .994 & .001 & .978 \\
\hline WLHHFMLSZ & -.629 & .533 & 3.732 & $.019^{*}$ \\
\hline WLHHSOCLPRT & -.873 & .418 & 3.230 & $.0072^{*}$ \\
\hline WLHHTRNING & .949 & 2.584 & .709 & $.004^{* * *}$ \\
\hline WLHHPERCPTN & .425 & 1.530 & 1.921 & .166 \\
\hline WLHHATTITUDE & -.553 & .575 & 2.304 & .129 \\
\hline WLHHVSNPLN & 1.653 & 5.220 & 21.510 & $.000^{* * *}$ \\
\hline WLHHIGA & 2.265 & 2.631 & 1.974 & .160 \\
\hline WLHHEXTRNLSPT & .735 & 2.086 & 34.464 & $.000^{* * *}$ \\
\hline WLHHINCME & .011 & 1.007 & 10.813 & $.001^{* * *}$ \\
\hline Constant & -6.525 & .001 & & \\
\hline
\end{tabular}

Table 15: The Maximum Likelihood Estimates of the Econometric Model

$$
\begin{array}{cc}
\text {-2 Log Likelihood Ratio } & 71.543 \\
\text { Pearson Chi-Square }\left(\mathrm{X}^{2}\right) & 17.977^{* * *} \\
\text { Correctly Predicted (Count } \left.\mathrm{R}^{2}\right) & 95.6^{* * *} \text {,** and } \\
* \text { Significant At 1\%, 5\% And 10\% Probability Level, Respectively. }
\end{array}
$$

The various goodness of-fit measures validate that the model fits the data well. The likelihood ratio test statistics exceeds the Chi-square critical value, indicating that the hypothesis that all coefficients except the intercept are equal to zero is rejected. The value of Pearson Chi-square test shows the overall goodness of-fit of the model at less than 1\% probability level. Other summary statistics for goodness of fit, which are not based directly on the distance between the observed and fitted values, are the various measures of classification accuracy. An intuitively appealing way to summarize the result of a fitted logistic model is via a classification table. This classification is the result of cross-classifying the outcome variable, y, with a dichotomous variable whose values are derived from the estimated logistic probabilities. In this approach, estimated probabilities are used to predict group membership. Presumably, if the model predicts group membership accurately according to some criterion, then this is thought to provide evidence that the model fits.

Binary logistic regression model as shown in the above parts was used to estimate the factors affecting women led SHGs member savings in Wolaita Soddo town administration. As a result, most of the outcomes of the model analysis are quite relevant and indicative of the existing reality.

Among the 12 factors considered in the model, 7 variables were found to have a significant 
Influence on determining the women led SHGs members saving improvement with less than $10 \%$ of the probability level. These variables include women-led households' education level (WLHHEDUC), family size (WLHHFAMSZ), social participation (WLHHSOCLPRT), training (WLHHTRNING), members perception (WLHHPERCPTN), engagement in income generating activities (WLHHIGA), and house holds' income (WLHHINCME). Whereas, the rest 5 of the 12 explanatory variables (see Table 15) were found to have no significant influence on women led SHGs members saving improvement.

\section{Conclusion and Recommendations}

\subsection{Conclusion}

The result of this study, as discussed in the foregoing parts of this paper underlines that the factors affecting womenled households' savings to be complex and interrelated, requiring a multifaceted and all-round interventions for improving savings and factors affecting it. Therefore, this study undoubtedly accepts that saving improvement could be eliminated by broad based and multi-pronged factors affecting women-led households.

The finding showed that the null hypothesis, WLHHs saving improves in consecutive years was rejected as the saving trends of women-led households did not improve in consecutive years. The alternative hypothesis, WLHHs saving did not improve due to the influence of various factors that hinder the trend of saving improvement was accepted.

Household savings are the main domestic source of funds to finance capital investment, which is a major driver of long-term economic growth. In this study, factors affecting women-led household savings at Wolaita Sodo town were analyzed by making use of cross sectional data of the SHG women-led household saving data spanning from 2014-2016 were used. The survey was conducted based on the data collected from various types of saving records of sample savers. In this study, both descriptive and binary logit econometric model analyses were used for analytical purpose.

This study has attempted to identify the contextual factors that influence women-led households' savings in Wolaita Soddo town. Furthermore, attempts were also made to identify the potential factors that influence saving improvement of SHGs members and to quantify the relative importance of the various factors. Moreover, an effort was made to assess the current savings and the status of women member of the Self-Help Group in the study area by comparing those members that their saving had improved and those that their savings had not improved in their respective SHGs.

The descriptive statistics with regard to the socio-economic factors revealed that SHGs members who are saving had improved were relatively with lesser family size and more literate than the members whose saving did not improve. Moreover, they were found to have larger family size and economically inactive labor force than the members whose saving did not improve.

With regard to women-led SHGs members' social participation, the average social participation of members improved their saving participates in not higher than two. Moreover, improved their savings had taken more training than the not improved. This implies that members improved their saving are relatively because of intensive training they had participated. In addition, major reasons for improving saving were reported that being a member of SHG helped them to improve saving. It was also found that those improved saving had relatively better engagement in income generating activities than that of reluctant SHGs members. Also, it was mirrored that women-led SHGs members improved their savings were able to earn extra money to improve their weekly saving than others. Similarly, annual income of women-led households of SHGs members had helped members to improve their saving higher than others.

The logistic regression model estimated using maximum likelihood estimation procedure to identify factors influencing the women-led households of SHGs members saving. The model has correctly predicted the saving improvement and not improvement by $95.6 \%$ of the overall observation.

Correctly predicted those whose saving had improved and correctly predicted whose saving did not improve value of the econometric model were $85 \%$ and $90.4 \%$, respectively. Among the 12 explanatory variables included in the model, women-led households' family size, education level, social participation, training, perception, IGAs, and annual income were found to influence SHGs members saving improvement.

\subsection{Recommendation}

Based on the above descriptive statistics and econometric results the following policy implications are forwarded. These may be broadly viewed as strengthening SHG institutional set up in promoting small scale household saving.

- As the study has shown, major social celebration had been seen to negatively affect women-led household savings in the area. Therefore, the town's government as well as the NGOs should work to change the attitude towards saving improvement through community mobilization and awareness creation trainings, workshops and seminars to reduce consumption expenditures on these social celebrations in order to enhance women-led household savings.

- The analysis has shown that family size and women-led household savings are strongly and negatively related. Therefore, proper attention has to be given to limit the increasing population in the study area. This might be achieved by integrated family planning program and awareness creation trainings for women.

- On the other hand, the effect of women-led households' education level on saving improvement had confirmed significant role of the variable in consideration for saving improvement. The more educated household led women, the higher will be the probability of saving relatively significant amount of their income because of better awareness to adopt and practice interventions, which the twenty first century so badly demands. So, strengthening both formal 
and informal education and vocational or skill training should be promoted to enable women-led households to improve their saving.

- As the study had shown, trainings that SHGs members received had positively affecting women-led household savings in the area. Trainings including the importance of saving, basic business skills and IGAs that is major important variable affecting the women-led household saving. It also has direct relation to make community members to perceive that what they are doing have positive impact in their life. Due to that women-led household perceive that being a member of SHG had helped them to improve their saving.

- Emphasis should also be given to promoting IGAs as it has direct relationship to improve households' incomes and in turn contributes in the improvement of capital development in increasing the saving culture. Therefore, the SHG promoting organizations have to concentrate to strengthen IGAs among members in different trainings in such a way that group dynamics, entrepreneurship, common fund development that enhance their capacity by improving their skills, knowledge and attitude towards saving.

- According to the analysis of this study, the availability of group vision and future plan has been seen to be positively affecting women-led household savings in the area. This grants the SHG members to work towards the desired goals having commonly agreed strategies through increasing the saving culture and amount. So, the SHG promoting organizations have to facilitate SHG members in preparation of group vision and plan that enhance their capacity by creating affinity working towards achieving the vision.

- Finally, it is the felt need of the author, to see research studies on the role of SHGs in empowering women that influencing government policy in general, factor affecting rural poor women SHG saving in particular of the same, at a broader scope in the nation.

\section{References}

i. Adams, D., \& Sherraden, M., 2006. What We Know About Effects of Asset Holding: Implications for Research on AssetBased Anti-Poverty Initiatives. Working Paper No. 191; Center for Social Development, Washington University.

ii. Ahmedabad and M S Sriram,(2008) Building Bridges between the Poor and the Banking System A Study of Sanghamithra Rural Financial Services Research carried out under the Sir Ratan Tata Trust Fund for Research Collaborations in Micro Finance Indian Institute of Management

iii. Aloysius P. Fernandez (1995). Self Help Groups: The Concept, MYRADA, Rural Management Systems Series Paper - 22, Bangalore India

iv. Anoruo and Y. Ahmad (2001) Causal Relationship between Domestic Savings and Economic Growth: Evidence from Seven African Countries/ African Development Bank, 2001.

v. Argarwal, S. 2004. Real Interest Rate: Its Level and Dynamics -- Evidence from Selected Emerging Economies. Development Planning Centre Institute of Economic Growth Delhi-110007.

vi. Bezabih Emana.2000. The Role of New Varieties and Chemical Fertilizer Under Risk: The Case of Smallholders in Eastern Oromia, Ethiopia. Ph.D. dissertation, University of Hannover, Shaker Verlung, Germany.

vii. Cheng, P.; Hanna, S.; \& Montalto, C. (1998). Do Households Make Saving and Investment Decisions Together? Proceedings of the 44 th Annual Conference of the American Council on Consumer Interests, 96-101.

viii. Cronje, Mark , (2009). Creating Savings Culture for the Black Middle Class in South Africa - Policy Guidelines and Lessons from China and India. University of Stellenbosch, South Africa

ix. Das, S. K. (2012). Best Practices of Self Help Groups and Women Empowerment: A Case of Barak Valley of Assam. Far East Journal of Psychology and Business, 7(3), 29-51.

x. Deaton, A. 1999. Saving in Developing Countries: Theory and Review. Proceedings of the World Bank Annual Conference on Development Economics.

xi. Deaton, A.S., (2005). Franco Modigliani and the Life Cycle Theory ofConsumption.Banca Nazionale del Lavoro Quarterly Review.

xii. Dhanya Jagadeesh (2015) The Impact of Savings in Economic Growth: An Empirical Study Based on Botswana/ International Journal of Research in Business Studies and Management Volume 2, Issue 9, September, PP 10-21

xiii. Ethiopian Society of Population Studies (2008). Gender inequality and women empowerment:

xiv. Haile A.(2013), "Determinants of domestic saving in Ethiopia: An autoregressive distributed lag (ARDL) bounds testing approach"', Acadamic Journal of Economics and International Finance vol.5(6),pp248-257

xv. Hall, R.E., (1978). Stochastic implications of the life cycle-permanent income hypothesis. Journal of Political Economy 86 (6), pp. 971-87.

xvi. In depth analysis of Ethiopian Demographic and Health Survey. Addis Ababa, Ethiopia.

xvii. Flavin, MA., (1981). The Adjustment of Consumption to Changing Expectations about Future Income. Journal of Political Economy, Vol. 89, No. 5 pp. 974-1009.

xviii. Fukuyama, F. 1995. Trust: The social virtues and the creation of prosperity. New York: Free Press.

xix. Fekadu Negusie, (2014). The Impact of Self Help Group Approach in the Lives of Beneficiaries at Household Level: The Case of Children's Home Society and Family Services, Hosanna Family Empowerment Program 
xx. Frederking, L.C. 2001. Is There an Endogenous Relationship Between Culture and Economic Development? Journal of Economic Behavior and Organization. Vol. 48 pp.105-126.

xxi. FDRE, MoFED (2010): "Growth and Transformation Plan (GTP) Draft"; Ministry ofFinance and Economic Development, Addis Ababa

xxii. FDRE (2010): "Government of Ethiopia Consultation of the Growth and Transformation Plan", Opening Remarks on Behalf of the Development Assistance Group; Wednesday 29, September, 2010.

xxiii. Franco, F. 2004. Household Saving in China and LCH. Prepared for the Conference on Chinese Economy and Security, June 14-15.

xxiv. Faruqee, H. and Husain, A.1998. Saving Trends in Southeast Asia: a Cross-Country Analysis. IMF Working Paper WP/ 95/39, April.

xxv. Getaneh Gobezie, April 6, 2006 Gender, Poverty and Micro-enterprise Services in Ethiopia: Why only Few Women are Joining? A Paper Presented at National Fair - Women's Empowerment in the New Millennium 2006 (Organized by the Women Development Initiative Programme (WDIP) in Ethiopia.

xxvi. Ghosh and Asis Kumar Pain, 2004: What Determines Household Savings in India? New Delhi, India.

xxvii. Giovannini, A. 1985. Saving and the Real Interest Rate in LDCs" Journal of Development Economics. Vol. 18: 197-217.

xxviii. Gobotswang, K., 1998: Determinants of the nutritional status of children in a rural African setting: The case of Chobe District, Botswana. Food and Nutrition Bullet in 19/1,

xxix. Goldstein G., Barro I., (1999). Etude sur le rôle et l'impact des services et produits d'épargne du secteur informel et des institutions de micro-finance en Afrique del'Ouest, PNUD-FENU, Unité Spéciale pour la Microfinance (SUM), Micro Save-Africa, mimeo.

xxx. Journal of Economics and Sustainable Development, (Vol.4, No.3, 2013). Determinants of Rural Household Savings in Ethiopia: The Case of East Hararghe Zone, Oromia Regional State

xxxi. Jeanne Hogarth, Amberly Hazembuller and Michael Wilson; How Much Can the Poor Save? Education and Research, Consumer and Community Affairs, Federal Reserve Board.India 2002.

xxxii. Jaya S. Anand, 2004. Citizen Empowerment through Participation Workshop Addressing poverty through Self Help Groups: A CASE STUDY, Kerala, India

xxxiii. Losayza N., K. Schmidt-Hebbel and L. Servén, (2000).What Drives Private Saving across the World? The Review of Economics and Statistics, 82 (2), pp. 165-181.

xxxiv. Luis René Cáceres / Giordano Dell-Amore Foundation Research Center on International Cooperation of the University of Bergamo/ Foreign Resources, Domestic Savings And Economic Growth: The Case Of Central America / Savings and Development, Vol. 19, No. 4 (1995), pp. 393-404

xxxv. Manyama, M. M., (2007). Instilling a Culture of Savings in South Africa. An MSc Thesis Presented at Gordon Institute of Business Science, University of Pretoria, South Africa.

xxxvi. Mikesell, R. and Zinser. J. 2001. The Nature of the Savings Function in Developing Countries: A Survey of the Theoretical and Empirical Literature, Journal of Economic Literature, Vol. 11, No.

xxxvii. Mason, A. 1988. Saving, Economic Growth and Demographic Change. Population andDevelopment Review, Vol. 14, No. $1: 113-144$.

xxxviii. Masih, R. and S. Peters (2010). "A Re-Visitation of the Savings-Growth Nexus in Mexico, "Economics Letters, Vol. 107, p. 318-330.

xxxix. Masilela, E. 2006. Introductory Speech at the Press Launch of the SASI Savings Month Initiative.

xl. Moon, U. (2011). Role of Self Help Group - Bank Linkage Model In Women Empowerment. [Article]. Asia Pacific Journal of Research in Business Management, 2(6), 47-65.

xli. Modiglianni, F. and Brumberg, R. 1986. Utility Analysis and the Consumption Function: An Interpretation of CrossSection Data. In Kurihara, K. (ed.) Post Keynesian Economics, New Brunswick: Rutgers University Press.

xlii. Meghan Entz, Janet Karsgaard, Michael Salomons (2016) an Overview of Savings and Self-Help Groups, Their Contributions to Improved Food Security, and How to Improve their Function

xliii. MoFED (2012).Macroeconomic Developments in Ethiopia

xliv. Mohan, R. (2006) causal Relationship between Savings and Economic Growth in Countries with Different Income levels. Economics Bulletin, 5(3), 1-12.

xlv. Nga, M.T., (2007). An Investigative Analysis into the Saving Behavior of Poor Households in Developing Countries: With Specific Reference to South Africa. An MSc Thesis Presented to the Department of Economics, University of the Western Cape. South Africa.

xlvi. Nagi Bairamli and Vassilis Kostoglou (2010), The Role of Savings in the Economic Development of the Republic of Azerbaijan; International Journal of Economic Sciences and Applied Research

xlvii. Noah Yusuf, Gafar .T. Ijaiya and Muftau.A. Ijaiya. (2008) Informal Financial Institutions and Poverty Reduction in the Informal Sector of Offa Town, Kwara State in Nigeria: A Case Study of Rotating Saving and Credit Associations (ROSCAS).

xlviii. N. Retsinas \& E. Belsky (Eds.), Building assets, building credit: Creating wealth in low-income communities. Washington, DC: Brookings Institution Press. 
xlix. Nwachukwu, T. and P. Odigie, (2009). What Drives Private Saving in Nigeria. Centre for the Study of African Economies Conference, University of Oxford.

l. OECD (2010), "Household Savings", in OECD Fact book 2010: Economic, Environmental and Social Statistics, OECD Publishing.

li. Panda, D. K. (2009). Measuring Impacts Of Women Self-help Group-based Microfinance In Eastern India: An Analysis Through Econometric Models. [Opinion]. Globsyn Management Journal, 3(2), 41-48

lii. Pahlavani M., Verma R. and Wilson E. (2006): "The Role of Capital Formation and Saving in Promoting Economic Growth in Iran"; Faculty of Economics, the University of Sistan and Baluchistan, Zahedan, Iran

liii. Philippe Aghion, Diego Comin, Peter Howitt, Isabel Tecu (2009) When Does Domestic Saving Matter for Economic Growth? / Harvard business school/ Working Paper 09-080

liv. Prinsloo, J.W., (2000).The saving Behavior of the South African Economy. Occasional PaperNo 14, South African Reserve Bank. South Africa.

lv. R. Ghosh and Ashish Kumar Pain. What Determines Household Savings in India? 2004. India.

lvi. R. Verma, E. Wilson R. Verma, E. Wilson (2007) the role of capital formation and saving in promoting economic growth in Iran

lvii. Ranjula B. Swain (2006). Can Microfinance Empower Women? Self-Help Groups in India Department of Economics, Uppsala University, Sweden

lviii. Rogerson, A., \& Hewitt, A. (2009). The International Aid System 2005-2010 Forces For and Against Change.

lix. Robert M. Solow (1956), a Contribution to the Theory of Economic Growth the Quarterly Journal of Economics. Vol. 70.The MIT Press

lx. Rogg, C., (2006). Asset Portfolios in Africa Evidence from Rural Ethiopia. UNUWIDER,Centre for the Study of African Economies, University of Oxford.

lxi. Robinson, J. (2004). Squaring the circle? Some thoughts on the idea of sustainable Development. Ecological Economics $48,369-384$.

lxii. Department for International Development (UK). Research Paper No. 2006/ 145.

lxiii. Sajid,G.M., and M.Sarfaraz (2008). "Savings and Economic Growth in Pakistan: An Issue of Causality," Pakistan Economic and Social Review, Vol. 46, p. 17-36

lxiv. Sandhu G. K. (2013) A Study of Norms and Functioning of Self-help Groups In Punjab.

lxv. Serhan Ciftcioglu, Nermin Begovic (2010) Problems and Perspectives in Management, Volume 8, Issue 3, 2010/Are domestic savings and economic growth correlated?, Evidence from a sample of Central and East European countries

lxvi. Sherraden, M. (1991). Assets and the poor: A new American welfare policy. Armonk, NY: M. E. Sharpe, Inc.

lxvii. Schreiner, M., \& Sherraden, M. (2007). Can the poor save? Savings and asset building in Individual Development Accounts. New York: Aldine de Gruyter.

lxviii. Schultz, T. P., (2005). Demographic Determinants of Savings: Estimating and Interpreting the Aggregate Association in Asia. Discussion paper series IZA DP No. 1479. Yale University and IZA Bonn

lxix. Schmidt-Hebbel K., Serven L., and Solomano A. (1996). Saving and Investment: Paradigms, puzzles, policies. World Bank Research Observer, 11 (1), 87-117.

lxx. Sinha, D., (1999) Saving-Investment Relationship in Japan and Other Asian Countries,CJES Researcher Papers No. 985.

lxxi. Tesoriero, F. (2006). Strengthening communities through women's self help groups in South India. Community Development Journal, 41(3), 321-333.

lxxii. Tobin Williams, 1999. 'Relative income, absolute income and saving' in Money, Trade and Economic Growth: Essays in Honor of John $\mathrm{H}$.

lxxiii. Vetrivel, S. C., \& Mohanasundari, M. (2011). Self-Help Groups: Women Empowerment and Social security in Tamilnadu. [Article]. Advances in Management, 4(3), 55-59.

lxxiv. Varshney A., (July, 1993). The Journal of Development Studies: Special Issues Beyond Urban Bias. Frank Cass \& Co. Ltd, vol.29, No. 4, London. 